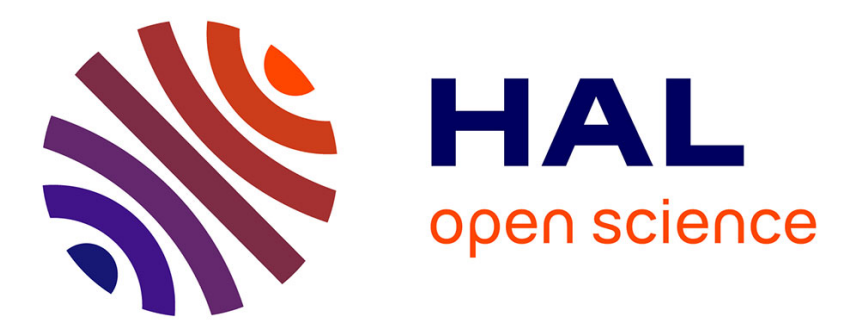

\title{
Implementing the Shared Environmental Information System (SEIS) and environmental policies in Central Asia
}

Diana Mangalagiu, Nicolai Dronin, Matthew Billot

\section{- To cite this version:}

Diana Mangalagiu, Nicolai Dronin, Matthew Billot. Implementing the Shared Environmental Information System (SEIS) and environmental policies in Central Asia. Environmental Science and Policy, 2019, 99, pp.29 - 36. 10.1016/j.envsci.2019.05.017 . hal-03484350

\author{
HAL Id: hal-03484350 \\ https://hal.science/hal-03484350
}

Submitted on 20 Dec 2021

HAL is a multi-disciplinary open access archive for the deposit and dissemination of scientific research documents, whether they are published or not. The documents may come from teaching and research institutions in France or abroad, or from public or private research centers.
L'archive ouverte pluridisciplinaire HAL, est destinée au dépôt et à la diffusion de documents scientifiques de niveau recherche, publiés ou non, émanant des établissements d'enseignement et de recherche français ou étrangers, des laboratoires publics ou privés.

\section{(ㄷ)(1) $\$$}

Distributed under a Creative Commons Attribution - NonCommerciall 4.0 International 


\title{
Implementing the Shared Environmental Information System (SEIS) and environmental policies in Central Asia
}

\author{
Diana Mangalagiu
}

NEOMA Business School

59 rue Pierre Taittinger

diana.mangalagiu@ouce.ox.ac.uk

\section{Highlights}

- $\quad$ After almost three decades, the management of environmental information in Central Asia still bears many of the hallmarks of the Soviet regime. It is technocratic, integrated in centrally planned economies, and embedded in a culture of nondisclosure to citizens and the international community.

- $\quad$ SEIS is an essential part of the ongoing reform of environmental governance in Central Asia, supervised by UNECE and significant progress has been made in all five countries. SEIS' development is particularly important for the progress on three environmental policies focusing on public access to environmental data and information.

- $\quad$ The Aarhus Convention requires citizens to participate in environmental decisionmaking and act as 'informed citizens'. Implementation of the convention in Central Asia still falls far short of the expectations of many local NGOs. Further SEIS improvement could increase the number of end-users of environmental data in both civil society and the private sector.

Implementation of Integrated Water Resource Management (IWRM), including the creation of Water User Associations (WUAs) is underway in the region, providing increasingly reliable information on water intake in irrigated areas. SEIS helps 'citizen science', which could become an essential tool for collecting environmental data and information in remote regions of Central Asia.

Implementation of Integrated Pollution Prevention and Control (IPPC) is just starting in the region. SEIS can improve the decentralization and transparency in monitoring and reporting decentralization and transparent monitoring of industrial emissions.

\section{Introduction}

Access to environmental data and information has been recognized as a critical aspect of environmental policy as it conditions decision making at all levels (Kobayashi, 2012; Engel- 
Cox and Hoff, 2005). In recent decades, numerous initiatives facilitating access to environmental data have been elaborated and implemented in an increasing number of countries. ${ }^{1}$ One such key initiative is the Shared Environmental Information System (SEIS), a joint initiative of the European Commission and European Environment Agency to establish with the Member States an integrated and shared EU-wide environmental information system (EC, 2008). SEIS' three dimensions - Content, Infrastructure and Cooperation - are meant to facilitate systematic environmental assessments and reporting, by interlinking existing data and information flows relevant for national authorities in their monitoring and assessment activities and by advancing sharing and comparability of environmental indicators to harmonize environmental monitoring requirements.

SEIS has already proved useful for environmental assessments and environmental policy beyond EU Member States. For example, SEIS contributes to Environmental Performance Reviews (EPRs) conducted by the United Nations Economic Commission for Europe (UNECE) in Central Asia. EPRs are invaluable voluntary instruments in the region aiming to assess the progress countries have made in reconciling their environmental and economic targets and in meeting their international environmental commitments. In addition, EPRs promote the convergence of environmental policies throughout the region, and since 2017, have included the review of relevant goals and targets of the 2030 Agenda for Sustainable Development.

While significant progress has been made, there are still limitations in the provision of environmental data and information. The availability and accessibility of datasets and related information vary significantly per thematic area (air pollution, climate change, water etc.) and approaches taken by countries to generate, share and present information - based on different national legislative backgrounds, ministerial setups, competencies and strategies - can differ significantly, create inconsistencies and complicate comparisons (UNECE, 2016). Moreover, institutional and financial barriers arising from accessing existing data and information, coupled with license conditions for its use, may limit such access (Beniston et al., 2012). In some cases, data content or its monitoring prove to be politically sensitive.

Nevertheless, the UNECE policy promoting SEIS and facilitating data harmonization across the 50 pan-European countries has had an observable positive impact on Central Asian countries' noticeable progress regarding the dissemination and comparability of environmental

\footnotetext{
${ }^{1}$ Global Earth Observation System of Systems (GEOSS), European Soil Data Centre (ESDAC), Water bodies in Europe (WISER) etc.
} 
data and information (CAREC, 2013). However, progress along one fundamental principle of SEIS - making citizens active users of environmental data - has seen very limited advancement in Central Asia. In general, regional public demand for environmental information is still weak and primarily limited to a few governmental agencies and research institutes (UNECE, 2019). However, there is evidence that grassroots level demand for environmental data is growing as demonstrated by some environmental NGOs and citizens that collect and share their own environmental data on issues they are interested in.

This paper discusses the prospects to increase citizens' demand for environmental information in Central Asia in the course of implementing environmental policy reforms. It reviews three important policies being implemented in the region, namely the Aarhus Convention, the Integrated Water Resource Management (IWRM) and the introduction of the Integrated Pollution Prevention and Control (IPPC) system. Having selected these three policies based on their strong focus on access to environmental data and information, and their break with the old Soviet approach to environmental policy by encouraging new users of data to emerge. The advancement of the three policies is assessed over the last two decades to understand how their development is related to the collection and access to environmental data and information in the region, particularly regarding SEIS' implementation.

The analysis is based on secondary data from EPRs and State of Environment Reports (SOERs) for the five Central Asian countries, Aarhus Convention national implementation reports, IWRM and IPPC implementation data, reports on progress in establishing SEIS in the region, data and reports from national State Statistics Committees and relevant ministerial databases, as well as World Bank and UNECE publications on the implementation and reform of environmental policies in the region.

\section{Current development of SEIS in Central Asia}

Since the collapse of the USSR, external pressure from international actors (organizations, conventions, research institutions, programs, donor community etc.) has been the key driver to modernizing Central Asia's environmental data and information collection. Such pressure, as well as growing concern about environmental issues and especially water management in the region over the last decade, has positively impacted the region's establishment of international standards for environmental data, making them comparable with those of 
developed countries (Adelle, Biedenkopf and Torney, 2017; Abdullaev, 2014). While SEIS is today the main gateway for environmental data and information in the region, it is not a standalone initiative. SEIS must be regarded as an essential part of environmental governance reforms implemented in Central Asia since the mid-1990s under UNECE's supervision.

According to the first SEIS progress review (UNECE, 2016), the impetus towards establishing SEIS and facilitating data harmonization across the 50 pan-European countries has had a positive impact in most countries. For example, dissemination, application and comparability of environmental indicators and harmonization of environmental monitoring requirements has noticeably advanced. The progress review found that of the 67 SEIS-related datasets under investigation, $51 \%$ were available across all national websites, but few countries provided a very large majority or nearly all of the 67 data sets online (UNECE, 2016; Aggestam, 2019).

Despite only joining SEIS in 2011, Central Asian countries perform within the average. Kazakhstan and Kyrgyzstan are even comparable with the advanced EU countries in terms of providing most datasets online. In addition, among the ten countries studied in-depth by the review, Kyrgyzstan is featured as one of the most advanced countries and scored higher than France and Austria in terms of environmental datasets online accessibility on national websites and user-friendliness (UNECE, 2016). Overall, Central Asian countries provide most required datasets as well as information regarding the methodologies used to source and produce the data on their national websites.

However, regional problems with collecting, organizing, storing and exchanging environmental data and information remain, most notable is the weak coordination process of collection, storage and exchange between different data producers and users. In addition, data concerning some environmental indicators is absent and units of measurement are sometimes national (CAREC, 2013; UNECE, 2016; UNECE, 2019). Moreover, even when data is collected and used in the SOERs, it is not necessarily utilized in environmental policy design and implementation.

\section{Current development of environmental policy reforms in Central Asia}

Reshaping environmental policy in Central Asian countries has been ongoing for two decades, but the USSR's legacy lives on in many institutions in the region with their technocratic central planning and lack of data sharing practices (Burkhanov, 2018; Sievers, 
2003). This section assesses how the development of SEIS can contribute to the region's implementation of the following three important environmental policies selected for their strong focus on access to environment-related data and information.

\subsection{The Aarhus Convention}

Embracing the Aarhus Convention's three 'pillars' requires profound democratic change for former Soviet republics. The first pillar of access to information sets in place rights that directly undermine former Soviet republics fundamental culture secrecy. The second pillar of public participation also poses difficulties for officials for whom the highest praise is to be considered a 'professional' or an 'expert', while the third pillar of access to justice actually breaks new ground for these emergent nations still developing their judicial systems.

The implementation of the Aarhus Convention is challenged by two major inherited problems, namely centralized planning and governance coupled with generally low public interest in environmental problems (Sievers, 2003). Although environmental activism and protests in Central Asia have occurred, primarily linked to gold-mining companies polluting water supplies in Kyrgyzstan (Wooden, 2013), or offshore oil and gas extraction in Kazakhstan and Turkmenistan (Jones Luong and Weinthal, 1999; Weinthal and Watters. 2010). In Central Asia, the Convention is a legal mechanism guaranteeing certain rights and a healthy environment for private actors combatting ingrained authoritarian tendencies in the region (Sievers, 2003).

The Aarhus Convention's impact can be measured by the use of the tools provided by the Convention to civil society actors, namely the number of requests from NGOs or citizens answered or declined annually by environmental ministries, or the number of legal actions brought by such parties with reference to the Aarhus Convention provision (Zaharchenko, 2009). However, comprehensive data on the matter is still lacking in Central Asia as the principal sources remain the reports published by the Compliance Committee of the Aarhus Convention. Since its establishment in 2002, the Committee has dealt with concrete issues related to the implementation of the convention by the parties. Three reports (released in 2008, 2011 and 2016) cover all law cases considered by the Compliance Committee, including those declared inadmissible, except for pending cases for which decisions were not ready at the time of publication. ${ }^{2}$

\footnotetext{
2 www.unece.org/env/pp.
} 
Among the former Soviet republics, only the Russian Federation and Uzbekistan have not joined the Aarhus Convention. According to the first Convention Secretariat's Synthesis Report on the status of its implementation, Kazakhstan was assessed to be the most advanced post-Soviet states while Kyrgyzstan, Tajikistan, and Turkmenistan the least advanced, although even in Kyrgyzstan and Tajikistan hopeful signs could be noticed (UNECE, 2005). However, the second and third reports (Andrusevych et al., 2011; Andrusevych \& Kern, 2016) indicated implementation remained limited and a decade later the gap between countries persisted. The four Central Asian countries signatories of the Convention implemented Aarhus centers in partnership with $\mathrm{UNECE} \mathrm{OSCE}^{3}$ to act as bridges between NGOs, local administration and the private sector, to support environmental assessment and participatory decision-making, facilitate public access to information in environmental matters and to raise awareness of environmental and health-related risks. Kazakhstan has established 15 such centers since 2001, with the first of Tajikistan's 7 centers dating to 2003. While Kyrgyzstan also implemented two centers and Turkmenistan one, these are no longer active. Although SEIS' gradual development in the region since 2011 has helped implement the Convention in terms of identification of the types of necessary data, their potential sources and required infrastructure, numerous difficulties remain in implementing participatory instruments and making data accessible.

Regarding the use of the Aarhus Convention's tools by civil society in Central Asia, some information exists for Kazakhstan. The first Convention Secretariat's Synthesis Report provided only one example of a state-owned enterprise obliged to provide information upon public request in Kazakhstan (UNECE, 2005). The Case Law of the Aarhus Convention Compliance Committee report of 2011 (Andrusevych et al., 2011) provided descriptions of five legal proceedings in Kazakhstan (a figure comparable with EU country averages), only one of which was initiated by citizens, the others were brought by the Almaty-based NGO Green Salvation, which actively employs provisions of the Aarhus Convention in legal cases over information access and in appeals to Kazakhstan courts. ${ }^{4}$ The third report (Andrusevych and Kern, 2016) added one further case concerning Kazakhstan. Turkmenistan is also mentioned in the second report regarding a legal proceeding submitted by an NGO from

\footnotetext{
${ }^{3}$ OSCE: Organization for Security and Co-operation in Europe

${ }^{4}$ In 2013 "Green Salvation" successfully appealed to the Committee of Compliance of the Aarhus Convention on the project of construction ski resort Kok Zhailau area of the Ile-Alatau National Park near Almaty (UNECE, 2017b).
} 
Moldova alleging non-compliance with the Convention because national legislation only allows citizens of Turkmenistan to establish NGOs or participate in their activities in the country (Andrusevych et al., 2011).

The Aarhus Convention was met with tremendous enthusiasm by NGOs in the former Soviet republics. However, aside from Kazakhstan, no Central Asian country has made significant progress in implementing the Convention. Zaharchenko (2009), referring to personal communications with NGO activists across the region, notes that many of them expressed their disappointment in this situation. ${ }^{5}$

While such limited progress can be seen as disappointing, a number of factors seem to have contributed to this. These include the repeated reorganization of nature protection ministerial bodies, lack of experienced and qualified public officials, low-level media awareness of ecological problems, and limited technical capacity for public access to digital media (UNECE, 2011). Moreover, the complexity of the Convention's implementation, which depends on the national specificities of procedural legal regimes, has also contributed to limited implementation. Indeed, most EU countries took 10-15 years to undertake real domestic regulation adjustment to accommodate the Aarhus Convention (Müllerová et al. 2013). For example, the French government only launched a policy of open data and a portal to facilitate the transparency of public action in all areas in 2011 (Marc, 2013).

\subsection{Integrated Water Resource Management (IWRM)}

Central Asia has a long history of water management because of its importance to the region's economic development (Dukhovny and de Schutter, 2011). The current structure of water management was inherited from the Soviet system. Responsibilities and tasks are spread over different administrative bodies at various levels, governed by multiple ministries and financed according to varying criteria/rules and channels. For example, there is no forum for collaborating on the common problems of any river basins (UNECE, 2000). The implementation of SEIS since 2011, and particularly its cooperation pillar promoting the management of human resources, inputs and networking, should contribute to better water management structures in the region.

\footnotetext{
${ }^{5}$ Among the key reasons mentioned was an incomplete legal base. For example, no Central Asian country has defined "environmental information" in full compliance with the Aarhus convention at the level of law or governmental decree (Zakharchenko, 2009).
} 
The IWRM concept is based on a two-level system of national water resources management through the establishment of (1) the basin administrations and basin councils of river systems and (2) water user associations (WUAs). Basin-level organizations have been created in very different initial conditions, structures and types (UNDP, 2004). Basin borders require precedence over administrative borders which is not case in any Central Asian republic where administrative borders rarely coincide with watersheds. In most Central Asian countries, the main stakeholders are state-owned companies, although in some cases stakeholders also include central government agencies operating within nationally-defined basin boundaries, inter-governmental and quasi-governmental commissions, non-governmental basin councils and various hybrid basin bodies. ${ }^{6}$ Central Asia has favorable conditions to develop river basin management institutions: its semi-arid climate makes water scarcity issues sufficiently significant to stimulate action while the homogeneity of its water users presents few barriers to such action (Kemper et al., 2005). The initial distribution of resources among basin stakeholders clearly has favored irrigators in the basin, who account for over $90 \%$ of water consumption.

River basin organizations

In Kyrgyzstan, the Water Code adopted in January 2005 includes some provisions influenced by the IWRM approach, such as the establishment of a National Water Council (in 2006) tasked with coordinating activities in the water sector and defining the hydro-geographic boundaries of the principal river basins, river basin councils and basin management plans (UNECE, 2009). However, the river basin management principle, including establishing a basin council for each principal river basin in the country, has not been implemented. Instead, in 2009 the World Bank initiated a pilot project in the Talas basin to establish a basin water administration and a basin council, with similar arrangements being made for the Chu basin under EU supervision (UNECE, 2009).

Tajikistan's water policy is embodied in the Water Code, adopted in 2001 (UNECE, 2004), where the government stated that IWRM by hydrographic basin was the most efficient and rational method. The first implementation step consisted of geographically limited pilot projects carried out in collaboration with international partners (Ibid.). The Water and Irrigation

\footnotetext{
${ }^{6}$ In the most advanced French system, the river basin committees are a tripartite structure, with members representing the state government (including public water users), municipalities and civil society (including those representing private water users). The committees act as parliaments consisting of 61-114 representatives (depending on basin size) with no more than $20 \%$ coming from executive bodies (UNDP, 2004).
} 
Sector Reform started in 2009 with the objectives of transferring irrigation system management to the WUA and establishing sub-basin units (UNECE, 2011). It was proposed to delineate four major river basins, however, the latest EPR report states that despite amendments to the Water Code in 2012, no change is observable in river basin management, the above delineation being postponed until 2016-2025 (UNECE, 2017a).

Uzbekistan's water policy was elaborated in 2003 and envisaged the transition from an administrative territorial approach to a two-level system of basin irrigation management involving the introduction of market relationships at all water use levels (UNECE, 2010). The particularity of Uzbekistan's water policy is that the borders of basins and sub-basins were established according to irrigation units. While the main task of basin administrations of irrigation systems (BAISs) is to implement IWRM principles across the country, the observed progress is very slow (Dukhovny et al. 2013).

In Kazakhstan, the Water Code established in 2003 considered water and land occupied by water bodies to remain the exclusive property of the State and with highly centralized regulation by the governmental Committee on Water Resources (CWR). The Water Code, however, mentioned the principle of water basin management and requirements for consultation of various governmental and non-governmental entities, for example, WUAs and water-related NGOs (2003 Water Code, Article 10). A decree issued in 2005 went one step further towards IWRM by describing more explicitly the role of River Basin Organizations (RBOs) to "develop a master plan of integrated use and protection of water resources for each basin of the main rivers" and "establish information database of water bodies and ensure access to all organizations and individuals concerned" (UNECE, 2008b). In practice, the functions of RBOs has changed little compared with Soviet Basin Water Departments and they remained understaffed: 182 people for all 8 basins, ranging from 16 for the Chu-Talas to 32 for the Balkhash-Alakol. The lack of clearly defined tasks, human resources and budget deficiencies, coupled with overly centralized management and underdeveloped use of information technology has slowed progress towards effective IWRM. Since 2005, eight river basin councils have been created with United Nations Development Programme (UNDP) support to provide a forum for stakeholder involvement. Nevertheless, for most basins, no meetings other than those initially organized with UNDP support were held and the various actors remain uninvolved in river management plan development (UNECE, 2008b).

Turkmenistan has yet to implement IWRM, and although its Water Code of 2004 contains some provisions regarding the necessity of basin management (Article 102), current water management practices in the country are primarily based on the territorial-administrative 
principle (Volovik, 2010). Hopes to move toward IWRM principles are associated with the country's accession to the UNECE Convention on the Protection and Use of Transboundary Watercourses and International Lakes in August 2012. The development of a roadmap for implementation of IWRM principles in Turkmenistan was planned for 2016-2017 and multiple training sessions have been run by $\mathrm{CAREC}^{7}$ since 2015 .

\section{Water User Associations (WUAs)}

The second essential element of IWRM is the establishment of WUAs within the hydrological boundaries. Ideally, WUAs are established by groups of farmers and other water users to collectively manage, operate, maintain and develop a local irrigation and drainage system (Zinzani, 2015). Kyrgyzstan was the first to introduce WUAs in the region and the establishment of WUAs, along with the transfer of the management of irrigation networks to the associations, was regarded as key water sector reforms in Kyrgyzstan (Zoï, 2014). The first resolution on WUAs in June 1995 stipulated their formation within administrative borders rather than hydrological ones. However, in August 1997, the government enacted the second WUA resolution that promoted the establishment of WUAs within hydrological boundaries irrespective of administrative borders (Alymbaeva, 2004). These associations are still in the process of formation (Zoï, 2014).

In Tajikistan, a model charter for WUAs was elaborated and officially approved by the government in 1999. The Water and Irrigation Sector Reform in 2009 called for the transfer of irrigation system management to WUAs within each sub-basin's irrigation units (UNECE, 2011).

In Uzbekistan, the first WUAs were created in 2000 in the Khorezm Region and in 2002 in the Fergana Valley (Moss and Hamidov, 2016). However, this transition from administrative to hydrographic management units is still ongoing, even in the very productive Fergana Valley (Dukhovny et al. 2013).

In Kazakhstan, the Water Code of 2003 supports IWRM principles and registration of WUAs as non-governmental organizations. Nevertheless, Kazakh WUAs remain based on administrative boundaries (former collective farms) and only in some districts on basin principles (Zinzani, 2015).

\footnotetext{
${ }^{7}$ CAREC: Central Asia Regional Economic Cooperation
} 
Turkmenistan's 2005 agricultural reform in land use established larger agricultural entities (Volovik, 2010). However, this reform did not intend to transform "dayhan" (farms) into WUAs.

Several authors emphasize the lack of transparency and participatory role of farmers in managing WUA activities across Central Asia. According to Sehring (2009), the newly established WUAs are undermined by detrimental practices such as patronage and unauthorized water withdrawal. Moreover, farmers consider WUAs as yet another bureaucracy imposed on them rather than a means of introducing collective action water management (Abdullaev et al. 2010; Dukhovny et al. 2008; Moss and Hamidov, 2016). Most WUA councils leave authority with paid officials and, in particular, the WUA chairman. The influence of individual farmers is largely limited to each WUA's annual general assembly and, particularly in Uzbekistan, the Soviet-style system tends to be a template for WUA governance (Schlüter et al. 2010).

The effectiveness of WUAs in water and crop productivity terms is difficult to judge due to scant reliable data. Some case studies conducted in Kyrgyzstan, Uzbekistan and Tajikistan show mixed results (Gunchinmaa and Yakubov, 2010). ${ }^{8}$ While Central Asian countries are divergent in terms of agriculture and rural economy, the implementation of basin management and WUAs in all countries is almost identical. While SEIS' development in the region, particularly its cooperation and content pillars, could have better-promoted cooperation and the emergence of relevant WUA governance structures, progress has been slowed by difficulties in implementing participatory instruments and data accessibility.

All Central Asian countries must find a way to jointly manage their most vital regional resource - fresh water. Principal hope still rests on the IWRM concept, despite its limited positive impact in the region. However, its limited regional results need to be compared to global outcomes arising from implementing IWRM. In most countries, reforms took 15-20 years to implement (Kemper et al., 2005). ${ }^{9}$ Frequently cited instances of largely successful WUAs include those

\footnotetext{
${ }^{8}$ Gunchinmaa and Yakubov (2010) provided results of performance of three Kyrgyz, Uzbek and Tajik WUAs over a four-year period (2002-2005). Comparing the yields in 2005 versus past yields, and WUA yields versus national average yields show some improvements in the case of Kyrgyz and Tajik WAUs and decrease (by 4-9\%) in the case of Uzbek. However, all farmers themselves blamed for the performance not only water regime but other constraints (lack of fertilizers, machinery etc.).

${ }^{9}$ For example, in the case of the Alto-Tietê basin in Brazil, almost 15 years of reform have been insufficient to fully operationalize the new water resources management system anywhere in the state. In the case of the Jaguaribe basin in Brazil, despite strong political will to adopt the new management scheme, its full implementation required over 12 years. Spain adjusted its water legislation policy in 2004 to much more closely resemble an IWRM approach than it did 20 years ago. Poland faced a decade long delay in revising its national
} 
created in Mexico, Turkey, and Nepal, where farmers with well-established irrigation management traditions were able to develop truly autonomous and self-governing WUAs. Many other examples around the world, however, present a very different picture with numerous financial, political, institutional and administrative constraints hindering the emergence of efficacious WUA and IWRM systems (Moss and Hamidov, 2016).

\subsection{Integrated Pollution Prevention and Control (IPPC)}

The IPPC concept was defined by the European Commission (EC) in 1996. A fundamental part of the concept (Directive 96/61/EC) is that a facility should not only meet specific technical requirements but also be operated and maintained with the best available techniques (BAT). It also requires the EC to organize an exchange of information between Member States and the industries concerning BAT (Hitchens et al., 2001).

The BAT approach proved to be the most difficult to implement in Central Asia among the three policies analyzed in this study. None of Tajikistan's (UNECE, 2004, 2012a, 2017a), Uzbekistan's (UNECE, 2010) or Turkmenistan's (UNECE, 2012b) EPRs mention the BAT approach. The analysis of environmental policy documents in Central Asia also reveals the low priority of BAT and IPPC.

The first EPR on Kyrgyzstan in 2000 criticized the post-Soviet environmental standards based on the maximum permitted emission levels (MPELs) as discouraging polluters from modernizing technology. The report states that new standards based on BAT but that do not entail excessive costs (BATNEEC) should be adopted in the medium term (UNECE, 2000a). Despite noting a few seminars for managers of several large companies conducted in 2003 and 2004, the 2009 EPR recognized the lack of progress regarding implementing the BAT approach with emission limits (e.g. for air or water) for a given facility continuing to be calculated based on MPEL and the maximum allowable concentrations (MACs). Despite earlier recommendations to adopt a more realistic set of either $\mathrm{WHO}^{10}$ or EU environmental standards, Kyrgyzstan approved better air and water quality standards in 2004 following the standards' revision made by the Russian Federation in 2003 (UNECE, 2009). Furthermore, local industrial managers' perception of new norms for some pollutants as too strict and standards being too complex (sometimes involving hundreds of parameters) often resulted in standards being neglected altogether. The major recommendation of the report was to encourage the application

water law, from 1991 to 2001 which created some significant problems for basin management agencies (Kemper et al., 2005).

${ }^{10}$ WHO: World Health Organisation 
of BATs in all industrial sectors and, in particular, to reduce Sulphur dioxide $\left(\mathrm{SO}_{2}\right)$, particulate matters (PMs) and other emissions into the air.

Currently, only Kazakhstan has undertaken meaningful efforts to implement the BAT approach, which is discussed in detail in Kazakhstan's EPRs. The first report in 2000 recognized the importance of IPPC because of growing environment pressure from extracting and processing crude oil as well as from the broader petrochemical industry. The first step needed to focus on the adoption of realistic MACs for a low number of pollutants while simultaneously ensuring their correct monitoring with the report providing a 15 -year time frame for BAT implementation in existing sources (UNECE, 2000b). The second EPR in 2008 refers to the 2007 Environmental Code which called for the introduction of IPPC for large industrial facilities in 2008 but concedes there are serious capacity constraints for its adoption. Reference to two cleaner production facilities in Pavlodar and Almaty are made in the report, but with no information on specific activities of either (UNECE, 2008b). The implementation of SEIS in the region and particularly its content and infrastructure pillars could help identify the types and sources of data along with the technical infrastructure required for appropriate pollutant monitoring.

The Green Development Program (Zhasyl Damu) for 2010-2014 also envisaged developing guidelines and plans for transiting to BAT based standards for large industrial facilities, referring to the first list of national BATs adopted by the government in 2008. The list contains two generic BAT documents (compared to seven in EU countries) and six industry-specific reference documents (compared to 26 in EU countries, including off-shore and on-shore oil production and non-ferrous metal industries. The program sets ambitious targets of reducing air emissions by $5.9 \%$ and pollutants discharged to water resources by $3.5 \%$, using 2009 as a baseline. A 2012 survey of five industries confirmed that such targets could be achieved using the BAT approach. These results were combined with an earlier pilot benchmarking exercise undertaken as part of the World Bank's Joint Economic Research Program (JERP) which showed significant potential for reduced dust emissions, raw materials, energy, water utilization and waste. However, critiques of the survey argue that it was carried out on a limited and ad-hoc basis and that among the proposed technical and technological solutions for pollution reduction the highest proportion is still related to end-of-pipe techniques (WB, 2012).

There is some evidence that Kazakhstan's government has low confidence in the IPPC's prospects. Despite OECD and EC recommendations to lighten environment quality standards 
making them more realistic and corresponding to existent monitoring capacities, the Kazakh government - similarly to the Kyrgyz government - approved new rules in 2012 with stricter norms for air quality, close to the Russian Federation standards adopted in 2003. Despite official acceptance of BAT, emission limits in permit application processes are based on historic levels of pollution and background concentrations rather than on BATs (WB, 2012). Today Kazakhstan has two permit application systems in place: 1) Environmental Emissions Permit, ranking environmental exposure of specific industrial processes based upon compliance with sanitary standards, a system inherited from the USSR, and 2) the Integrated Environmental Permit, which ranks environmental exposure based on IPPC principles. As companies are free to choose either system, there is still no evidence in Kazakhstan of companies using the latter as most enterprises considering complying with former easier. Studies and surveys among industrial managers showed very little awareness about IPPC and BATs within Kazakh companies (Nugumanova and Frey, 2017; WB, 2012). According to experts, this situation resembles that of EU industries in the mid-1990s, before IPPC and BAT concepts were formally adopted in 1996 (WB, 2012).

Collectively, Central Asian countries have achieved very little since the early 2000s when IPPC first appeared in official documents. In 2000 Kazakhstan planned to achieve results within 15 years (UNECE, 2000b), but not much has happened to date (Nugumanova and Frey, 2017). ${ }^{11}$ Some EU countries adopted the BAT approach as early as 1984 . Nevertheless, 20 years after its adoption in the EU, studies focusing on the BAT's impact on the economic performance and viability of facilities used cautious language, concluding that facilities that have adopted BAT and achieved a good environmental performance are only viable in the long run (Hitchens et al., 2001). According to the first OECD implementation assessment of BAT across various countries (e.g. China, India, New Zealand), the major weakness of the approach are the extreme time costs in preparing to launch the policy. Compiling primary BAT documents takes up to six years, which is too long to keep pace with the technological evolution of many industrial sectors. Some countries (e.g. Russian Federation), which managed to complete the first stage in a much shorter time (1-2 years), seem to have done so by sacrificing documentation quality (OECD, 2018).

\footnotetext{
${ }^{11}$ Very similarly, in the Russian Federation the first pilot projects on the BAT approach have been elaborated on voluntary basis for five companies in 1998. While the BAT approach was mentioned for the first time in the Environmental law of 2002, a BAT-based policy to prevent and control industrial emissions was officially introduced only in 2014, determined by amendments to the Federal Law on Environmental Protection. The policy entered into force in 2018 (OECD, 2018).
} 


\section{Implications for SEIS implementation in Central Asia}

The slow implementation pace of the three selected policies as analyzed above provides grounds for a cautious assessment of environmental policy reform in Central Asia. These policies require much better environmental data than is presently publicly available at the national level in the region. Further development of SEIS in Central Asia could fill existing data gaps in relation to these particular policies as SEIS emphasizes the importance of the free flow of environmental information from providers to users ("easily accessible to all users") and localization ("managed as close as possible to its source") of data collection and presentation. Moreover, citizens must be both consumers and important providers of environmental information (CAREC, 2013). These principles are very much in line with the Aarhus Convention which requires that individuals participate in environmental decisions, acting as 'informed citizens' which necessitates access to information related directly or indirectly to a plan or program likely to affect the environment.

According to SEIS principles, environment-related data and information should be stored in compatible and digitally interconnected electronic databases. However, today the national websites of Central Asian governments provide only highly aggregated and disconnected datasets on the state of the environment, rendering this information of little use for concerned citizens. Environmental NGOs attempt to collect their own local data, for example, for the assessment of green areas in cities. ${ }^{12}$ Thus, the issue of data availability and sharing, the content pillar of SEIS, has the highest priority in the Aarhus Convention.

SEIS' development could help existing Aarhus centers, which have been instrumental in bringing together relevant stakeholders and coordinating activities, to become more effective (ENPI, 2015). Kazakhstan was a pioneer in establishing the State Fund of Environmental Information under the Aarhus centers in 2005. This fund was designed to play the role of a hub where all information flows would be concentrated and, after appropriate processing, communicated to the concerned data users (CAREC, 2013). Such information hubs could play a bigger role in the Convention's implementation.

The EU's experience shows that, when meaningfully implemented, the Aarhus Convention significantly increases the number of environmental data users (Andrusevych et

\footnotetext{
${ }^{12}$ The Kazakh NGO Green Salvation, in the context of Aarhus Convention implementation, provides its own database on the state of green areas and many other original materials (for example, a map of "hot spots" in Almaty city) (see http://esgrs.org/?p=7682)
} 
al., 2011; Marc, 2011). Data availability and sharing facilitated by SEIS could similarly support the participation of citizens and NGOs in Central Asia in accessing justice and concretely in the submission of law cases to the Aarhus Convention Compliance Committee.

Introducing IWRM is essential to collect and share data on water quantity and quality in Central Asia. Since 1991, the functions of monitoring institutions have been significantly disrupted or ceased completely for some activities, a situation that is only now slowly improving. National responsibility for monitoring water quality and quantity is shared between several ministries, agencies and institutes. Their monitoring activities are not well coordinated and have been hampered by dire financial constraints for many years, which caused a substantial reduction in their monitoring networks and capacities since the USSR's collapse. Today, the monitoring capacity is clearly insufficient to provide reliable water data, for example, Kyrgyz official statistics show inexplicably large gaps (up to 20\%) between water extraction versus water use, even when allowing for water losses (UNECE, 2008a). In turn, the lack of reliable data causes problems with regard to proper water resource management, such as in the prioritization of actions and investments and impediments to the introduction of IWRM principles (UNECE, 2008a).

The analysis of SEIS's performance across the pan-European region shows that waterrelated data flows are at least accessible online. However, infrastructure efficiency issues need to be addressed to make data accessible (Aggestam, 2019), particularly in Central Asia. The accuracy of water statistics is totally dependent on information submitted by primary water users (thousands of companies), including farms and WUAs, and finally water utilities. With functioning WAUs, control over the accuracy and completeness of the information provided by the water users and water data producers at the farm level becomes possible. ${ }^{13}$ Water users need to introduce modern measurement devices and equipment in order to implement accurate accounting of water during intake and supply for domestic, household and agricultural use.

SEIS' development in Central Asia and its principle of encouraging citizen participation could attenuate the infrastructure inefficiencies observed in the region by enabling so-called 'citizen science' (Strasser et al., 2018). In line with IWRM, citizen science can be used to collect and provide environmental information about river basins. For example, a number of recent policy EU documents and initiatives, including those directly related to SEIS, highlight

\footnotetext{
${ }^{13}$ A pilot project in the Alamedin district of Kyrgyzstan revealed that only 552 from 1,937 registered water users submitted their statistical reports on water intake in 2013 (CAREC, 2013).
} 
the important role volunteers play in environmental monitoring of different environs, including freshwater resources (EU, 2013). The EU Water Framework Directive acknowledges the crucial role of citizens and citizens' groups for two main purposes: First, decisions on the most appropriate measures to achieve river basin management plan objectives involve balancing the interests of various groups. Second, it is anticipated that transparency in establishing specific objectives, measures and standards enhances the implementation and governance of citizens' role in environmental protection (Roy et al., 2012). Such benefits can be envisaged in Central Asia where smartphone apps for environmental citizen science can aid users to automatically provide a GPS location, submit photographs and information on water availability in canals, its improper timing of supply by hydro-technical services, drought events, salinization, cropland waterlogging in different irrigation units within hydrological boundaries, particularly in remote river basin areas that lack official monitoring. A pilot project introducing citizen science to river basin management in Central Asia was already implemented on the Naryn River in Kyrgyzstan (Buytaert, 2014).

The region's implementation of SEIS could impact the functioning of the compliance monitoring system in Central Asia and therefore help the introduction of IPPC. Currently, emission limits for each stationary source are determined according to methods inherited from the Soviet era and often only rough estimates for emissions are made on the basis on energy and material inputs, raising many doubts concerning basic environmental statistical accuracy (Balance and Pant, 2003). Environmental self-monitoring and reporting do not yet exist in practice in the region, as only a few companies monitor their emissions properly. Since good international practices entail open access to self-monitoring data and other environment-related information, new regulations for self-monitoring, self-reporting and handling confidential industrial data need to be introduced while facility-specific information of environmental significance needs to be made publicly available (UNECE, 2008b).

Thus, implementation of IPPC suggests the need for a new level of decentralization and transparency in monitoring and reporting environmental data. The BAT approach contains a requirement for continuous monitoring when possible and appropriate or high-frequency monitoring at least. Monitoring quarterly, as is the norm in Central Asia countries, is insufficient to meet EU BAT requirements (WB, 2014). In the EU, monitoring has been regulated and the minimum needed frequency and parameters have been defined according to sectors and environmental performance. Since it is the responsibility of each industry to comply with BAT, EU industries have implemented their own self-monitoring programs but where it 
falls to independent state laboratories to check the quality of companies' self-monitoring. The role of such self-monitoring is primarily to keep resource consumption and emissions low, which from an environmental point of view is the most essential task. In addition to this, companies' self-monitoring is used by authorities in enforcement as well as for yearly reporting purposes.

As noted previously, little progress has been made in advancing IPPC in the region and substantive progress would require a higher level of cooperation, the third pillar of SEIS.

\section{Conclusion}

Central Asia is broadly regarded as an economically limited region with multiple environmental and other problems inherited from its Soviet past. While the conventional view is that efforts reforming environmental policy in the region have not been effective, this review argues that significant progress has been made. Although some Central Asian countries (resource-rich Kazakhstan and the more financially challenged Kyrgyzstan) are more reformist than others (Tajikistan, Uzbekistan and particularly Turkmenistan), all five exhibit a significant level of formal implementation of the SEIS concept. At a regulatory level, all five countries have demonstrated a willingness to follow EU environmental standards and noticeable progress in relation to the dissemination, application and comparability of environmental information is observable. Simultaneously though, there remains little improvement in increasing public use of environmental data while the evidence shows that collection and use of real-time and spatially detailed data seem limited to a narrow niche market of providers and users (UNEP, 2018).

The three policies analyzed in this paper demonstrate the difficulties to link data to action, at both the policy and grassroots level. As shown here, SEIS could help to improve the overall implementation of these policies by addressing different problematic aspects (content, cooperation, infrastructure) that are presently impeding progress. Improvement in data content could increase the number of end-users of environmental data in both civil society and the private sector and help the implementation of the Aarhus Convention, which requires informed citizens to participate in environmental decision-making. SEIS' facilitation of participation in citizen science could help Water User Associations to obtain increasingly reliable information on water intake in irrigated areas and attenuate the infrastructure inefficiencies in the region. SEIS can improve the decentralization and transparency in monitoring and reporting emissions for industrial stationary sources and facilitate the introduction of the IPPC. 
Moreover, it is argued that a formalistic approach of evaluating SEIS implementation as a typical top-down process is insufficient to transform citizens into active environmental data users. Creating demand for environmental data at the grassroots level is indispensable and, by analyzing the conditions for increasing such demand in Central Asian countries, it has found significant potential for new users within WUAs. Further advancement regarding implementing SEIS' pillars and principles could bring new means of collecting and accessing environmental data and therefore facilitate further implementation of policies, such as the ones analyzed in this paper. Nevertheless, additional research needs to be dedicated to better understanding the users and usages of environmental data and information throughout Central Asia.

\section{References}

Abdullaev I, Kazbekov J, Manthritilake H. 2010. Water user groups in Central Asia: emerging form of collective action in irrigation water management. Water Resource Management, 24, 1029-1043.

Abdullaev, I. 2014, November. Transformations and current trends of water governance in Central Asia. In ReCCA-Conference 2014 (No. 212552). Institute of Agricultural

Development in Central and Eastern Europe (IAMO).

Adelle, C., Biedenkopf, K. and Torney, D. eds. 2017. European Union External

Environmental Policy: Rules, Regulation and Governance Beyond Borders. Springer.

Aggestam F. 2019. Setting the stage for a Shared Environmental Information System. Environmental Science and Policy. 92: 124-132

Alymbaeva, A. 2004. Institutional development of Water Users Associations in Kyrgyzstan, Thesis, Rochester Institute of Technology.

Andrusevych A., Alge T., Konrad C. eds. 2011, Case Law of the Aarhus Convention Compliance Committee (2004-2011), $2^{\text {nd }}$ edition, RACSE, Lviv.

Andrusevych A., Kern S. eds. 2016. Case Law of the Aarhus Convention Compliance Committee (2004-2014), $3^{\text {rd }}$ edition, RACSE, Lviv.

Ballance R., Pant B.D. 2003. Environment statistics in Central Asia: progress and prospects. ERD Working Paper, 36.

Bellinger, E., Lee, N., George, C. and Paduret, A. eds. 2000. Environmental Assessment in Countries in Transition, Central European University Press, Budapest. 
Beniston, M., Stoffel, M., Harding, R., Kernan, M., Ludwig, R., Moors, E., Samuels, P. and Tockner, K. 2012. Obstacles to data access for research related to climate and water: implications for science and EU policy-making, Environmental Science and Policy, 17, 4148.

Burkhanov, A., 2018. Policy-making styles in Central Asia: The Soviet legacy and new institutions. In Policy Styles and Policy-Making, 222-241. Routledge.

Buytaert W. 2014. Citizen science in hydrology and water resources: opportunities for knowledge generation, ecosystem service management, and sustainable development. Frontiers in Earth Science, 2, 26.

CAREC. 2013. Towards Implementation of Shared Environmental Information System (SEIS) in Central Asia. Analytical Review, Almaty, 42 P.

Carmichael, L., Barton, H., Gray, S., Lease, H., Pilkington, P. 2012. Integration of health into urban spatial planning through impact assessment: identifying governance and policy barriers and facilitators. Environmental Impact Assessment Review, 32 (1), 187-194.

Cinnirella, S., March, D., O'Higgins, T., Murciano, C., Sardà, R., Albaigés, J. and Pirrone, N. 2012. A multidisciplinary Spatial Data Infrastructure for the Mediterranean to support implementation of the Marine Strategy Framework Directive. International Journal of Spatial Data Infrastructures Research, 7, 323-351.

Clark, W.C., Mitchell, R.B. and Cash, D.W. 2006. Evaluating the Influence of Global Environmental Assessments. Global environmental assessments: information and influence. MIT, Cambridge, 1-28.

Danilyan, V.I. and Arskii, Y.M. 1993. Economics and environment in the Former Soviet Union. In: Economics and Environment in the Former Soviet Union and Czechoslovakia. Economic Commission for Europe. Discussion Papers, 2(4). United Nations, New York. Dukhovny V., Sorokin A., Stulina G. 2008. Should we think about adaptation to climate change in Central Asia? Adaptation to climate change: regional challenges in light of world experiences. Scientific Information Center of the Interstate Commission for Water Coordination, Tashkent.

Dukhovny V.A., Sokolov V.I., Ziganshina D.R. 2013. Integrated water resources management in Central Asia, as a way of survival in conditions of water scarcity, Quaternary international, 311,181-188.

Dukhovny, V.A. and de Schutter, J. 2011. Water in Central Asia: past, present, future. CRC Press/Balkema, Taylor \& Francis Group, London, UK. 
Eales, R.P. and Sheate, W.R. 2016. Effectiveness of policy level environmental and sustainability assessment: Challenges and lessons from recent practice. In Progress in Environmental Assessment Policy, and Management Theory and Practice, 67-93. EC. 2008. European Commission Communication, Towards a Shared Environmental Information System (SEIS), http://eurlex.europa.eu/LexUriServ/LexUriServ.do?uri=COM:2008:0046:FIN:EN:PDF Engel-Cox, J.A. and Hoff, R.M. 2005. Science-policy data compact: use of environmental monitoring data for air quality policy. Environmental Science and Policy, 8(2), 115-131. ENPI. 2015. East Region Synthesis Report. Building a Shared Environmental Information System with the Eastern Neighbourhood. Outcome of cooperation, 2010-2014. European Environment Agency.

EU. 2013. EU Shared Environmental Information System Implementation Outlook. Brussels, 25.1.

Farrell, A.E. and Jäger, J. 2006. Assessments of regional and global environmental risks: designing processes for the effective use of science in decision-making. Resources for the Future. In: Morrison-Saunders, A., Pope, J., Bond, A. eds., Sustainability Assessment. Gerasimova, K. 2014. The Importance of Sustainable Environmental Management in Central Asia: Old Legacy and New Challenges, Cambridge Central Asia Reviews, 1(1), 27 42 .

Gunchinmaa T., Yakubov M. 2010. Institutions and transition: does a better institutional environment make water users associations more effective in Central Asia? Water Policy, $12,165-185$.

Gunn, J. and Noble, B.F. 2015. Sustainability considerations in regional environmental assessment. Sustainability assessment handbook. Edward Elgar, Cheltenham, 79-102. GWP. 2014. Integrated water resources management in Central Asia: The challenges of managing large transboundary rivers, GWP Technical Committee, Edward Elgar, Northampton, MA, 79-102.

Hering, D., Borja, A., Carstensen, J., Carvalho, L., Elliott, M., Feld, C.K., Heiskanen, A.S., Johnson, R.K., Moe, J., Pont, D. and Solheim, A.L. 2010. The European Water Framework Directive at the age of 10: a critical review of the achievements with recommendations for the future. Science of the total Environment, 408(19), 4007-4019.

Hitchens D., Farrell F., Lindblom J., Triebswetter U. 2001. The Impact of Best Available Techniques (BAT) on the Competitiveness of European Industry. Joint Research Centre, Report EUR, 20133. 
James, T.E., Ballard, S.C. and Devine, M.D. 1983. Regional environmental assessments for policy making and research and development planning. Environmental Impact Assessment Review, 4(1), 9-24.

Jones Luong, P. and Weinthal, E. 1999. The NGO Paradox: Democratic Goals and Nondemocratic Outcomes in Kazakhstan, Europe-Asia Studies, 51(7), 1267-1284.

Joseph, C., Gunton, T. and Rutherford, M. 2015. Good practices for environmental assessment. Impact Assessment and Project Appraisal, 33(4), 238-254.

Kemper K., Dinar A., Blomquist W. eds. 2005. Institutional and policy analysis of river management decentralization. The Principle of Managing Water Resources at the Lowest Appropriate Level - When and Why Does It (Not) Work in Practice? Agriculture and Rural Development Department at the World Bank. Washington, DC.

Kobayashi, M. 2012. Forging policy and institutional frameworks to promote access to environmental information, Greening Governance, 35.

Kowarsch, M., Garard, J., Riousset, P., Lenzi, D., Dorsch, M., Knopf, B. 2016. Scientific assessments to facilitate deliberative policy learning. Palgrave Communications, 2, 16092. Lee, N. and George, C. eds. 2013. Environmental assessment in developing and transitional countries: principles, methods and practice, John Wiley \& Sons.

Lyhne, I. 2011. Between policy-making and planning: SEA and strategic decision-making in the Danish energy sector. Journal of Environmental Assessment Policy and Management. 13(3), 319-341.

Lyhne, I., Cashmore, M., Runhaar, H. and van Laerhoven, F. 2016. Quality control for environmental policy appraisal tools: an empirical investigation of relations between quality, quality control and effectiveness. Journal of Environmental Policy \& Planning, 18(1), 121 140.

Marc L. 2013. The French experience of environmental data sharing: why France supported the INSPIRE European initiative? Networks and Communication Studies, NETCOM, vol. 27, (1-2), 174-180.

Mason, M. 2014. So Far but No Further? Transparency and Disclosure in the Aarhus Convention. Transparency in Global Environmental Governance: Critical Perspectives, 83. Meiner, A. 2013. Spatial data management priorities for assessment of Europe's coasts and seas. Journal of coastal conservation, 17(2), 271-277.

Mitchell, R.B., Clark, W.C., Cash, D.W. 2006. Global Environmental Assessments. MIT Press, Cambridge, MA, 307-338. 
Moss T., Hamidov A. 2016. Where Water Meets Agriculture: The Ambivalent Role of Water Users Associations. R.F. Hüttl et al. eds. Society - Water - Technology, Water Resources Development and Management, 149.

Mukherji A. et al. 2009. Irrigation Reform in Asia. A Review of 108 Cases of Irrigation Management Transfer, http://www.iwmi.cgiar.org/research/projects/ project-map/.

Müllerová H. et al. Public Participation in Environmental Decision-Making: Implementation of the Aarhus Convention. Praha: Ústav státu a práva AV ČR, 2013, 255 s. ISBN 978-8087439-14-2.

Nugumanova, L. and Frey, M., 2017. Environmental governance and policy in Kazakhstan (No. 365). IOS Working Papers. Vancouver.

OECD. 2018. Best Available Techniques for Preventing and Controlling Industrial Pollution, Activity 2: Approaches to Establishing Best Available Techniques (BAT) Around the World, Environment, Health and Safety, Environment Directorate, OECD.

Roy, H.E., Pocock, M.J.O., Preston, C.D., Roy, D.B., Savage, J., Tweddle, J.C. \& Robinson, L.D. 2012. Understanding Citizen Science \& Environmental Monitoring. Final Report on behalf of UK-EOF. NERC Centre for Ecology \& Hydrology and Natural History Museum. Schlüter M., Hirsch D., Pahl-Wostl C. 2010. Coping with change: responses of the Uzbek water management regime to socio-economic transition and global change, Environmental Science and Policy 13, 620-636.

Sehring, J. 2009. Path dependencies and institutional bricolage in post-soviet water governance. Water Alternatives. 2, 61-81.

UNECE. 2016. Report on progress in establishing the Shared Environmental Information System in support of regular reporting in the pan-European region, https://www.unece.org/fileadmin/DAM/env/EMA/ece.batumi.conf.2016.8.e.pdf. Sievers E.W. 2003. The Post-Soviet Decline of Central Asia: Sustainable Development and comprehensive capital. London and New York: Routledge Curzon 248P.

Strasser, B.J., Baudry, J., Mahr, D., Sanchez, G. and Tancoigne, E., 2018. Citizen Science? Rethinking Science and Public Participation. Science and Technology Studies. Vancouver.

UNDP. 2004. Methodological Guideline: Establishment of River Basin Councils in Kazakhstan.

UNECE. 2000a. Kyrgyzstan Environmental Performance Review, Economic Commission for Europe, Committee on Environmental Policy, United Nations, New York and Geneva. 
UNECE. 2000b. Kazakhstan Environmental Performance Review, Economic Commission for Europe, Committee on Environmental Policy, United Nations, New York and Geneva. UNECE. 2004. Tajikistan Environmental Performance Review, Economic Commission for Europe, Committee on Environmental Policy, United Nations, New York and Geneva. UNECE. 2005. Synthesis Report on the Status of Implementation of the Convention, ECE/MP.PP/2005/18, April 12.

UNECE. 2008a. State Committee on Statistics, State Agency of Environmental Protection and Forestry, and UNDP. Statistical Compendium: Environmental protection in Kyrgyz Republic, Bishkek.

UNECE. 2008b. Kazakhstan Environmental Performance Review, Economic Commission for Europe, Committee on Environmental Policy, United Nations. New York and Geneva. UNECE. 2009. Kyrgyzstan Economic Commission for Europe, Committee on Environmental Policy. United Nations, New York and Geneva.

UNECE. 2010. Uzbekistan Environmental Performance Review, Economic Commission for Europe, Committee on Environmental Policy, United Nations, New York and Geneva. UNECE. 2011. Tajikistan, National report the implementation of the Aarhus convention in Tajikistan for 2008 - 2010, http://wedocs.unep.org/handle/20.500.11822/9637?show=full UNECE. 2012a. Tajikistan Environmental Performance Review, Economic Commission for Europe, Committee on Environmental Policy, United Nations, New York and Geneva. UNECE. 2012b. Turkmenistan Environmental Performance Review, Economic Commission for Europe, Committee on Environmental Policy, United Nations, New York and Geneva. UNECE, 2016. Fifth National Report on the implementation of the Aarhus Convention, Kyrgyz Republic.

UNECE. 2017a. Tajikistan Environmental Performance Review, Economic Commission for Europe, Committee on Environmental Policy, United Nations, New York and Geneva. UNECE. 2017b. Findings and recommendations with regard to communication ACCC/C/2013/88 concerning compliance by Kazakhstan.

UNECE. 2019. Development of the Shared Environmental Information Systems in Central Asia (forthcoming).

Vitolo, C., Elkhatib, Y., Reusser, D., Macleod, C.J. and Buytaert, W. 2015. Web technologies for environmental Big Data. Environmental Modelling \& Software, 63, 185-198.

Volovik I.Y. 2010. Assessment of Water Sector in Turkmenistan. Ashgabat, Turkmenistan, http://waterwiki.net/images/7/76/TM_Water_Sector_Assessment_Fin_Draft.pdf, last accessed 24.07.2018) 
WB. 2012. Modern Companies, Healthy Environment. Improving industrial competitiveness through potential of cleaner and greener production, World Bank 73471.

WB. 2014. Users and Uses of Environmental Accounts. A Review of Select Developed Countries, World Bank.

Weber, M., Krogman, N., Antoniuk, T., 2012. Cumulative effects assessment: linking social, ecological, and governance dimensions. Ecology and Society, 17(2), 22.

Weinthal, E. and Watters, K. 2010. Transnational environmental activism in Central Asia: the coupling of domestic law and international conventions, Environmental Politics, 19(5), $782-807$.

White, L. and Noble, B.F. 2013. Strategic environmental assessment for sustainability: A review of a decade of academic research. Environmental Impact Assessment Review, 42, 6066.

Wooden, A.E. 2013. Another way of saying enough: environmental concern and popular mobilization in Kyrgyzstan, Post-Soviet Affairs, 29(4), 314-353.

Zaharchenko T.R. 2009. On the Way to Transparency: A Comparative Study on Post-Soviet States and the Aarhus Convention. Kennan Institute Occasional Papers, $n^{\circ} 303$. Woodrow Wilson International Center for Scholars, Washington, D.C.

Zaharchenko T.R., Goldenman G. 2004. Accountability in Governance: The Challenge of Implementing the Aarhus Convention in Eastern Europe and Central Asia. International Environmental Agreements, 4(3), 229-251.

Zinzani A. 2015. The Reconfiguration of Participatory Irrigation Management in Water Users Associations. Cahiers d'Asie centrale, http://asiecentrale.revues.org/3142, last accessed on 22 December 2017.

Zoï. 2014. Strengthening Cooperation in Adaptation to Climate Change in Transboundary Basins of the Chu and Talas Rivers, Kazakhstan and Kyrgyzstan. 2014. Zoï Environment Network. 